UDC 027.7:[001.891.34:311.218]

LIUTSKO N. M.

National Library of Belarus (Minsk, Republic of Belarus),

e-mail: nativia1988@gmail.com, ORCID 0000-0002-8453-9681

\title{
DYNAMICS OF DEVELOPMENT OF UNIVERSITY LIBRARIES IN BELARUS: RESEARCH RESULTS
}

\begin{abstract}
Objective. The study of the effectiveness of individual processes in the activities of university libraries is a popular direction of scientific research. The work is aimed at a comprehensive study of the dynamics of development of the university libraries network in Belarus using the method of self-examination within the framework of the experimental toolkit. Method. The research was conducted using a new methodological toolkit for an independent quality assessment (voluntary certification) in the work of libraries of all types. Results. On the example of analyzing the activities of university libraries, a methodological toolkit has been tested. It is based on a matrix of library indices, a calculation algorithm of quality indices, criteria (performance indicators), and a system of weights and ratings of libraries. Conclusions. Constant comprehensive monitoring of the quality in the activities of the university libraries using up-to-date methods is today a defense against abolition; it helps to identify organizations that provide the highest quality services, show the strengths and weaknesses of library development, act as an information resource for making the right management decisions, both within a particular library and the network as a whole, and in librarianship at the state level. The development, implementation, and improvement of tools for studying the quality in the activities of university libraries undoubtedly have great potential.
\end{abstract}

Keywords: university libraries; dynamics of development; quality control; methodological toolkit; organizational management; Belarus

\section{Introduction}

The main advantage of a developed country with an innovative economy is associated with its human potential, which is largely determined by the effective educational careers of university graduates and the implemented results of scientific research. One of the conditions for competitiveness and demand for future specialists is the information base of the university, namely, a library having all the necessary resources for information support of the educational process and research activities and providing its users with the most demanded list of high-quality information and educational services.

At a time of change, accompanied, inter alia, by the optimization (unity, reduction) of a number of universities in the Republic of Belarus, the analysis of the potential of their libraries becomes especially relevant.

Practice shows that only the constant adaptation of libraries to changing conditions, organizing the new areas of activity (for example, monitoring the world scientific information flow, promoting scientific publications in the international scientific information space, analyzing the level of citation of university scientists, etc.) can help libraries prove their social importance and relevance, both at universities and in the state as a whole (Liutsko, 2020b, p. 42). Accordingly, under the conditions established by state development programs, a comprehensive system for monitoring, the activities of university libraries can be used as a fairly effective management mechanism. Its structure will help to take into account all relevant management issues and establish a "balance" between the interests of users (students, undergraduates, graduate students, university faculty) and economic efficiency; between the library as an effective organization and its ability to cope with future challenges. It will create a favorable environment for assessing and analyzing, measuring the quality of the university library as a whole, each of its structural departments, and each employee. 
Scientists and specialists around the world are working on the development of criteria for assessing the activities of libraries. Some researchers are aimed at examining the quality of a library through improving the efficiency of its services, which in turn affects the degree of user satisfaction. The quality of service to users and their satisfaction are important criteria for effective service management. Service quality is seen as a comparison of users' expectations before using the service and their impression after obtaining the requested service at the library (Dash \& Padhi, 2010, p. 12).

The research of the range and quality of e-services at the University of Tartu (Estonia) using the focus group method showed that technological and marketing approaches to studying the quality of e-services can be complemented by a social approach based on communication, user participation, and feedback. It should be noted that this research with the participation of users of the university library helped to identify fifteen criteria for the quality of electronic services (Einasto, 2014, p. 4).

Automated systems for analyzing user satisfaction with the quality of library services of university libraries ((LIBQUALC and Customer Service Excellence CSE) have allowed English experts to collect different opinions on this issue and make the right decisions (Atkinson \& Walton, 2017).

Assessing the quality in the activities of libraries from the standpoint of the effectiveness of the ongoing scientific research reflects the opinion of specialists from Novosibirsk (Russia) (Guzner \& Guzner, 2012).

Researches over the past ten years have forced the library community in Russia, Ukraine, and Belarus to think about developing comprehensive indices for studying the quality of library performance in general (Mykolenko, 2010; Soloidenko, 2011; Strelkova, 2016; Strelkova, 2017; Brykalov, Balyberdin \& Borodina, 2018; Dresher, Kosolapova, \& Klyuchenko, 2018; Pilko \& Mukhamedieva, 2019). Among them, researches were identified in the field of studying the quality of university libraries (Opekunova, 2013; Opekunova, 2017). Each research undoubtedly contributes to the overall methodology for studying the quality of library performance. However, at present, in our opinion, a more complex toolkit is the version developed by the Belarusian library scientist I. B. Strelkova in 2016 (Strelkova, 2016). This toolkit was first tested at the university libraries of the Republic of Belarus and formed the basis in the preparation of the Ph.D. thesis of the author of this article. The work is called "Qualimetric assessment in the activities of the library of a higher education institution based on the competence approach".

The purpose of this work is to comprehensively study the dynamics of development of the network of university libraries in Belarus using the method of self-examination within the framework of the experimental toolkit.

\section{Methods}

The study of the dynamics of the development of university libraries in Belarus consists of several interrelated stages. At the first stage, the participants in the research (directors of university libraries) were asked to complete a table of public library indices for two years (Strelkova, 2016, pp. 6-28). For the convenience of emailing and receiving data from respondents, the questions were formulated in the Google Forms program. The form included more than one hundred and ten (110) questions. The table of indices at the public library is formed by 5 sections: material and technical base (A); library fund (B); users $(B)$; stuff $(\mathrm{G})$; execution of library events (including unique events) (D). In each section, four components were identified: resources; availability; use, and development potential. To characterize unique events (from one to three learning, culturaleducational, and other events), directors of university libraries were offered a plan-description, in 
which it was required to indicate its purpose, type, target audience, and assess the impact on the library as a whole. In order to encourage directors of university libraries in Belarus to self-examine their departments, a questionnaire of seven questions was proposed. It made it possible to identify their attitude toward library innovations. With the aim of increasing the objectivity of the research results, an expert commission was organized represented by the Director of the Fundamental Library of Belarusian State University (BSU), the Scientific Library of Belarusian National Technical University (BNTU), and the Yanka Kupala State University of Grodno (SUG). It is noteworthy that members of the commission did not have the right to make decisions on their libraries. This mission was entrusted to three directors of other libraries. Based on the results of studying the respondents' answers, the members of the expert commission assigned points to each library on a 10-point scale (1-min, 10-max) (Strelkova, 2016, p. 32). Unique events (if any) were assessed by the expert commission according to five criteria, including innovative relevance (IR_1); financial efficiency (FE_2); cultural efficiency (CE_3); social significance (SS_4); global perspective (GP_5). Then the arithmetic mean is calculated for each library. Data for each university library from all experts are collated in a similar way. They form the final library rating (FLR). The library rating results are summarized in the table.

\section{Results and their discussion}

With a view to allowing conducting the research in Belarusian universities, the author of the article prepared official letters for rectors. The administration and the postgraduate study department of Belarusian State University of Culture and Arts provided invaluable assistance in preparing the documents. Forty directors of university libraries out of fifty-two possible ones took part in the research. Some of them were as respondents and experts. The number of indices, complex calculations, and great responsibility caused some difficulties from the side of the research participants, but they were able to overcome everything thanks to their involvement in the process and interest in the final results.

As expected, at the top of the ranking were university libraries of the leading institutions of higher education in Belarus (Table 1).

Table 1. Libraries - leaders in the rating

\begin{tabular}{|l|c|c|c|}
\hline \multicolumn{1}{|c|}{ Key indices } & \multicolumn{3}{|c|}{ The number of points for the main indices. Overall } \\
score/Rating index \\
\cline { 2 - 4 } & $\begin{array}{c}\text { BSU Fundamental } \\
\text { Library }\end{array}$ & $\begin{array}{c}\text { BNTU Scientific } \\
\text { Library }\end{array}$ & $\begin{array}{c}\text { Yanka Kupala } \\
\text { (SUG) Scientific } \\
\text { Library }\end{array}$ \\
\hline $\begin{array}{l}\text { A. Material and } \\
\text { technical resources }\end{array}$ & 10 & 8 & 6 \\
\hline $\begin{array}{l}\text { B. Library } \\
\text { fund }\end{array}$ & 10 & 8 & 6 \\
\hline C. Users & 9 & 8 & 7 \\
\hline D. Stuff & 6 & 7 & 7 \\
\hline $\begin{array}{l}\text { E. Execution of } \\
\text { library events }\end{array}$ & 4 & & 6 \\
\hline
\end{tabular}




\begin{tabular}{|l|l|l|l|}
\hline $\begin{array}{l}\text { Overall Rating of } \\
\text { University } \\
\text { Libraries }\end{array}$ & $39 / 7,8$ & $39 / 7,8$ & $32 / 6,7$ \\
\hline
\end{tabular}

Let us compare the results in the rating of libraries-leaders. With an equal number of points for the main indices and the same rating of the Fundamental Library of BSU and the Scientific Library of BNTU, the first one, having the highest rating works and develops unevenly. So, in the library with a high level (10 points) of the material and technical resources (the functional library building, large areas for serving users and staff work, modern ABIS, etc.); library fund with a high degree of circulation (10 points); user activity (9 points), there is staff loss (a decrease in the number of specialists with higher library education, a high turnover rate among competent and effective stuff) (6 points). It should be noted that the library does not position itself with the help of unique library events ( 4 points). However, this fact may currently be associated with the COVID 19 pandemic.

The scientific library of BNTU, unlike the Fundamental Library of BSU, does not have maximum points for each index (material and technical resources, library fund, users, library events -8 points each; staff -7 points), at the same time, it is dynamically developing in all areas of activity.

Scientific Library of Yanka Kupala State University of Grodno also does not have high scores (6 and 7 points) on performance indices. However, according to the results of expert analysis it focuses on systematic development and has good potential.

Other libraries that were given lower scores expressed a strong desire to introduce innovative forms in all performance indices. Their directors have plans to develop and implement unique measures after the abolition of quarantine measures in the country.

Intermediate results of the research were discussed at meetings of the Department of Information Resources and Communications at Belarusian State University of Culture and Arts (Minsk, Belarus).

\section{Conclusion}

Constant comprehensive monitoring of the quality in the activities of the university libraries using up-to-date methods is today a defense against abolition; it helps to identify organizations that provide the highest quality services, show the strengths and weaknesses of library development, act as an information resource for making the right management decisions, both within a particular library and the network as a whole, and in librarianship at the state level. The development, implementation, and improvement of tools for studying the quality in the activities of the university libraries undoubtedly have great potential.

It should be noted that twenty-eight directors of university libraries of the Republic of Belarus expressed a particular interest in further studying quality assessment methods and took part in a pedagogical experiment (Liutsko, 2020a, p. 175).

\section{REFERENCES}

Atkinson, I., \& Walton, G. (2017). Establishing Quality in University Libraries: Role of External Frameworks. New Review of Academic Librarianship, 23(1), 1-5. doi: https://doi.org/10.1080/13614533.2016.1271238 (in English) 
Brykalov, S. M., Balyberdin, A. S., \& Borodina, V. E. (2018). The relevance and efficiency analysis of functioning the scientific technical library at industrial enterprises. Bibliosphere, 3, 25-35. doi: https://doi.org/10.20913/1815-3186-2018-3-25-35 (in Russian)

Dash, N., \& Padhi, P. (2010). Quality Assessment of Libraries. Journal of Library \& Information Technology, 30(6), 12-23. $\quad$ Retrieved from https://www.researchgate.net/profile/Nrusingh Dash/publication/267564911 Quality Assessment of LLibraries/links/5735c95008ae9f741b29bc72/Quality-Assessment-of-Libraries.pdf (in English)

Dresher, Yu. N., Kosolapova, E. A., \& Klyuchenko, T. I. (2018). Balanced scorecard as a tool for managing information and library activities: some approaches to implementation. Bibliosphere, 2, 101-104. doi: https://doi.org/10.20913/1815-3186-2018-2-101-104 (in Russian)

Einasto, O. (2014). "Investigating e-service quality criteria for university library: a focus group study". New Library World, 115(1/2), 4-14. doi: https://doi.org/10.1108/NLW-09-2013-0067 (in English)

Guzner, I. A., \& Guzner, S. S. (2012). The assessment of academic libraries performance on the base of indicators. Bibliosphere, $\quad 4,7 . \quad$ Retrieved from https://www.bibliosphere.ru/jour/article/view/644/639 (in Russian)

Liutsko, N. M. (2020a). Formirovanie kvalimetricheskoy kompetentsii rukovoditeley universitetskih bibliotek Belarusi: sushchnost' i rezultaty pedagogicheskogo ekspirementa. Bibliyatechny vesnik, 12, 173-180 (in Russian)

Liutsko, N. M. (2020b). Osobennosti podgotovki specialistov v oblasti kvalimetrii dlya universitetskih bibliotek Respubliki Belarus. The phenomenon of libraries in the modern world : Proceedings of the All-Ukrainian scientific-practical conference, September 30, 2020, Mariupol, Ukraine, 2, 4245. Retrieved from http://mdu.in.ua/Nauch/Konf/2020/ zbirnik_2020-09-30_ch2.pdf\#page $=42$ (in Russian)

Mykolenko, R. (2010). Suchasni kryterii otsiniuvannia diialnosti bibliotek. Bibliotechna planeta - Library Planet, 4, 17-20. Retrieved from http://www.irbis-nbuv.gov.ua/cgibin/irbis nbuv/cgiirbis 64.exe?C21COM=2\&I21DBN=UJRN\&P21DBN=UJRN\&IMAGE FILE D OWNLOAD=1\&Image file name=PDF/bp 20104 7.pdf (in Ukrainian)

Opekunova, E. N. (2013). University Library as an object of evaluation. Bibliosphere, 2, 46-53. Retrieved from https://www.bibliosphere.ru/jour/article/view/810/791 (in Russian)

Opekunova, E. N. (2017). Evaluation parameters of a university library activity in the context of its tasks changes. Bibliosphere, 1, 38-45. doi: https://doi.org/10.20913/1815-3186-2017-1-38-45 (in Russian)

Pilko, I. S., \& Mukhamedieva, S. A. (2019). Evaluating effectiveness of libraries. Scientific and Technical Libraries, 3, 31-44. doi: https://doi.org/10.33186/1027-3689-2019-3-31-44 (in Russian)

Soloidenko, H. I. (2011). Suchasni kryterii ta pokaznyky otsiniuvannia yakosti roboty biblioteky. Modern problems of library activity in the conditions of information society : Proceedings of the 3nd Scientific-practical conference, September 29, 2011, Lviv, Ukraine. 155-160. Retrieved from http://ena.lp.edu.ua/handle/ntb/13103 (in Ukrainian)

Strelkova, I. B. (2016). Dinamika razvitiya bibliotek: metodicheskiy instrumentariy : nauchnoprakticheskoe posobie. Minsk : Belaruskaya navuka. (in Russian)

Strelkova, I. B. (2017). Non-material assets as a subject of library performance evaluation and the development environment. Scientific and Technical Libraries, 1, 26-35. doi: https://doi.org/10.33186/1027-3689-2017-1-26-35 (in Russian) 
ЛЮЦКО Н. М.

Національна бібліотека Білорусі (Мінськ, Республіка Білорусь), e-mail: nativia1988@gmail.com, ORCID 0000-0002-8453-9681

\section{ДИНАМІКА РОЗВИТКУ УНІВЕРСИТЕТСЬКИХ БІБЛІОТЕК БІЛОРУСІ: РЕЗУЛЬТАТИ ДОСЛІДЖЕННЯ}

Мета. Вивчення ефективності окремих процесів в діяльності університетських бібліотек $\epsilon$ популярним напрямком наукових досліджень. Робота спрямована на комплексне вивчення динаміки розвитку мережі університетських бібліотек Білорусі 3 використанням методу самообстеження в рамках експериментального інструментарію. Методи. Дослідження проводилося 3 використанням нового методичного інструментарію для проведення незалежної оцінки якості (добровільної сертифікації) роботи бібліотек усіх типів і видів. Результати. На прикладі аналізу діяльності університетських бібліотек апробований методичний інструментарій, в основі якого лежать: матриця показників бібліотеки, алгоритми розрахунку показників якості, критеріїв (індикаторів ефективності), системи ваг і рейтингів бібліотек. Висновки. Постійний комплексний моніторинг якості діяльності університетських бібліотек з використанням актуальних методик є сьогодні захистом від скасування; допомагає виявити організації, які надають послуги найвищої якості; показують сильні і слабкі сторони розвитку бібліотек; виступають інформаційним ресурсом для прийняття правильних управлінських рішень, як всередині конкретної бібліотеки і мережі в цілому, так і в бібліотечній справі на державному рівні. Розробка, впровадження та вдосконалення інструментів для вивчення якості діяльності університетських бібліотек безсумнівно має великий потенціал.

Ключові слова: університетські бібліотеки; динаміка розвитку; оцінка якості; методичний інструментарій; організаційний менеджмент; Білорусь 